
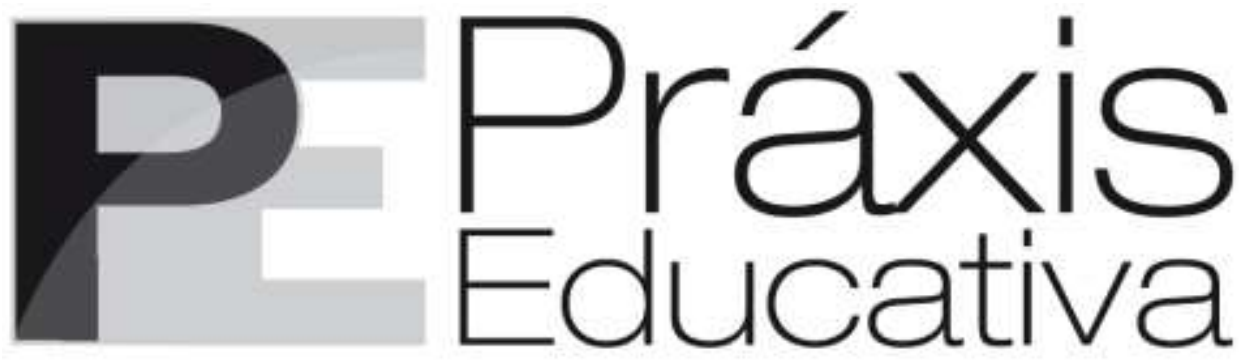

ISSN 1809-4031

elSSN 1809-4309

https://doi.org/10.5212/PraxEduc.v.17.19944.015

Entrevista

\title{
Entrevista com Pablo del Río - Desenvolvimento humano e desenho educativo: alguns desafios da escola contemporânea
}

\section{Interview with Pablo del Río - Human development and educational design: some challenges of contemporary schooling}

\section{Entrevista a Pablo del Río - Desarrollo humano y diseño educativo: algunos desafíos de la escolarización contemporánea}

Pablo del Río*

(iD) https://orcid.org/0000-0002-3722-6738

Elizabeth dos Santos Braga**

iD https://orcid.org/0000-0002-8115-249X

Teresa Cristina Rego ${ }^{* * *}$

(D) https://orcid.org/0000-0002-1164-8094

Ana Luiza Bustamante Smolka***

(D) https://orcid.org/0000-0002-2064-3391

\footnotetext{
* Foi professor de Psicologia e Comunicação na Universidade Complutense, Universidade de Salamanca e Universidade Carlos III (Madri e Salamanca, Espanha). Atualmente, trabalha com a evolução humana presente e futura, no projeto Futuros Humanos na Fundação Infância e Aprendizagem. E-mail: <p.delrio@me.com>.

** Doutora em Educação pela Universidade Estadual de Campinas (Unicamp). É Professora Doutora da Faculdade de Educação da Universidade de São Paulo - USP (São Paulo, SP, Brasil) e líder do Grupo de Pesquisa Linguagem, Memória e Subjetividade (GPLIMES - FEUSP/CNPq). E-mail: <elizabeth.braga@usp.br>.

*** Doutora em Psicologia da Educação pela Universidade de São Paulo (USP). É Professora Titular da Faculdade de Educação da USP (São Paulo, SP, Brasil) e líder do Grupo de Pesquisa Temas da Educação Contemporânea e a Perspectiva Histórico Cultural (FEUSP/CNPq). E-mail: <teresare@usp.br>.

**** Doutora em Educação pela Universidade Estadual de Campinas (Unicamp). É Professora Associada da Faculdade de Educação da Unicamp (Campinas, SP, Brasil) e líder do Grupo de Pesquisa Pensamento e Linguagem (FEUnicamp/CNPq).E-mail: <asmolka@unicamp.br>.
} 
Entrevista com Pablo del Río - Desenvolvimento humano e desenho educativo...

\section{Apresentação}

O texto de apresentação do livro Hereges, do premiado escritor cubano Leonardo Padura, elaborado pelo jornalista brasileiro Eric Nepomuceno (2015), inicia-se da seguinte maneira: "Uma grande história nas mãos de um escritor medíocre talvez resulte num livro razoável. Uma história medíocre nas mãos de um grande escritor talvez se transforme num livro interessante. Uma grande história nas mãos de Leonardo Padura é garantia de um grande livro. Hereges, por exemplo" (NEPOMUCENO, 2015, n.p.). Provavelmente, será essa a impressão que o leitor também ficará após a leitura da segunda parte da entrevista realizada com o espanhol Pablo del Río Pereda, reconhecido por seus estudos no campo da psicologia histórico-cultural. ${ }^{1}$

É com maestria, erudição e desenvoltura que del Río, atualmente jubilado na Universidade e investigando na Fundação Infância e Aprendizagem (FIA) ${ }^{2}$, ex-professor das Universidades Carlos III de Madri, Salamanca e Complutense de Madri, editor e revisor (em conjunto a Amelia Álvarez Rodriguez, sua esposa e colaboradora) da Coleção Obras Escogidas, de Lev Semionovitch Vigotski, analisa os pressupostos vigotskianos e os aplica no exame de uma série de problemas contemporâneos candentes em educação. Trata-se, indubitavelmente, de uma potente perspectiva teórica que, nas mãos hábeis de um grande pesquisador, resultam em reflexões extremamente instigantes.

Seus comentários e suas explicações tornam-se ainda mais fundamentais e provocadores frente aos enormes desafios que temos enfrentado atualmente na educação, impulsionando-nos a retomar o rico material ${ }^{3}$, desta vez nos atendo, especificamente, às suas reflexões que constituem uma interpretação arguta, profunda e lúcida de importantes conceitos da perspectiva históricocultural, de outros autores da psicologia e de outras áreas, assentadas no cotidiano escolar, com seus incontáveis problemas que o/a professor/a e a equipe pedagógica têm de enfrentar.

Com base nas pesquisas realizadas por Vigotski e seus interlocutores e continuadores (como Luria, Davydov e Galperin), bem como pela equipe da Fundación Infancia y Aprendizaje, Pablo del Río aponta três lacunas dos sistemas educativos e que também se mostram como problemas na própria forma de tratar o legado vigotskiano: a lacuna instrumental, a lacuna da atividade

${ }^{1}$ A entrevista foi realizada na Faculdade de Educação da Universidade de São Paulo (USP) e concedida às Professoras Elizabeth dos Santos Braga e Teresa Cristina Rego, durante a visita do Professor Pablo del Río às Faculdades de Educação da Universidade Estadual de Campinas (Unicamp) e USP, em 2012. Foi publicada uma primeira parte da entrevista na Revista Educação e Pesquisa, v. 39, n. 2, abr./jun. 2013, com ênfase nos comentários do pesquisador sobre a vida e a obra de Vigotski, nas suas reflexões sobre contribuições e limites da perspectiva histórico-cultural e sobre as condições de pesquisa nas Ciências Humanas hoje. Nesse mesmo artigo, há também mais detalhes sobre a vida e a produção de Pablo del Río, assim como uma bibliografia selecionada de artigos publicados por ele e em conjunto a Amelia Álvarez e outros autores. Seus livros publicados incluem a edição espanhola de Vygotsky's Writings, tais como Collected Works ou La Tragedia de Hamlet/Psicología del Arte, junto a Amelia Álvarez. Outras contribuições na perspectiva são: Explorations in Socio-Cultural Studies (coeditada com A. Álvarez e J. V. Wertsch), Sociocultural Studies of Mind (coediteda com J. V. Wertsch e A. Álvarez); Psicología de los Medios de Comunicación; Pigmalión. Informe sobre el impacto de la televisión en la infancia (em coautoria com A. Álvarez e M. del Río), artigos, tais como Vygotsky and beyond: Horizons for the future of Psychology (em coautoria com A. Álvarez), ou capítulos em livros editados sobre Vigotski e a abordagem histórico-cultural, como The Cambridge Companion to Vygotsky ou The Cambridge Handbook of Sociocultural Psychology.

2 Suas pesquisas atualmente enfocam as mudanças histórico-culturais e seu impacto nos desenhos (pessoal, cultural e geracional) da mente, na evolução humana presente e futura, no projeto Futuros Humanos na Fundación Infancia y Aprendizaje. Trata-se da instituição responsável pela publicação de vários periódicos como Infancia y Aprendizaje (desde 1978), hoje com o nome de Journal for the Study of Education and Development, e Cultura y Educacion (ou Culture and Education), com artigos em espanhol e inglês, e de obras de autores clássicos e contemporâneos, bem como por ações de investigação sobre o desenvolvimento humano, cultura e educação. Seu endereço eletrônico é http://www.fia.es

3 Agradecemos pela transcrição e pela tradução do espanhol às então doutorandas do Programa de Pós-Graduação da Faculdade de Educação da USP, Ana Maria Tejada Mendoza e Ana Paula Carneiro Renesto, e pela revisão de citações, também em espanhol, à Professora Marisa de Oliveira.

Práxis Educativa, Ponta Grossa, v. 17, e2219944, p. 1-24, 2022 Disponível em: <https://www.revistas2.uepg.br/index.php/praxiseducativa > 
significativa e o problema de se pensar mais no conhecimento do que na criança. Seu alerta faznos voltar à raiz da perspectiva histórico-cultural: a centralidade da pessoa concreta. Para Vigotski (1999a, 2000a, 2010, 2018), a psicologia e a educação devem voltar-se para a criança, o ser humano, em interação com os outros, nos seus diversos contextos (meios), na vida, em vez de se aterem à mente ${ }^{4}$, aos resultados, ao currículo (como algo apenas prescritivo, externo à atividade e estritamente ligado à aquisição de conhecimentos). É por essa razão que ele defende que o essencial na educação não é priorizar "[...] que a criança carregue um corpus de conhecimento acumulado pelas disciplinas, mas que incorpore todo um complexo de instrumentos, capacidades e modos de perceber e sentir que lhe permita reconstruir-se como pessoa e desenvolver suas funções para viver de modo mais pleno". ${ }^{5}$ Além disso, o entrevistado considera que a educação escolar precisa ser mais significativa para esses(as) alunos(as) concretos(as) e que nós, pesquisadores(as), precisamos colaborar na criação de instrumentos ou psicotecnias ${ }^{6}$, com "uma revolução da prática do desenho educativo". ${ }^{7}$ Sua ênfase no desenho educativo, na atividade significativa e na criança concreta tem relação com o diálogo entre a perspectiva ecobiofuncionalista - em especial von Uexküll (como o fizeram Köhler, Koffka e Lewin) e Bronfenbrenner - e a abordagem vigotskiana.

O ensino e a educação constituem para Vigotski modos generalizados e estabilizados de incorporação, ao desenvolvimento ontogenético, dos mecanismos mediacionais que cada cultura oferece às novas gerações. [...].

Nesta perspectiva, o modelo evolutivo não deve ser considerado sob a lente de um enfoque curricular baseado em "conteúdos" e "conhecimentos"; as capacidades psíquicas não são passiveis de serem "estudadas", não são aprendidas diretamente, mas são acessadas funcional, social e instrumentalmente: são as atividades reais da criança que determinam a pauta de seu desenvolvimento (Zaporozhets $\left.{ }^{8}, 1987\right)$. Assim, a intervenção educativa para melhorar o desenvolvimento funcional não deveria ser direcionada apenas aos conteúdos ou conhecimentos em si, mas ao enriquecimento do programa de atividades e formas de atividade das crianças em cada idade e cultura. E sim, as atividades de mediação planejadas poderiam e deveriam ser delineadas para uma melhor construção das funções desejadas, no ambiente escolar e no núcleo dos programas educativos. (DEL RÍO; ÁLVAREZ, 2011, p. 609 , grifos dos autores, tradução nossa).

$\mathrm{Na}$ visão do nosso entrevistado, a necessidade da preocupação com o desenvolvimento e a aprendizagem de todos/as, bem como a lacuna na atividade significativa não é só uma questão escolar, mas social e cultural.

Outro importante aspecto destacado é que as psicotecnias vigotskianas são tanto do intelecto quanto do sentimento. Vigotski não se ateve apenas às funções intelectuais ou cognitivas,

\footnotetext{
${ }^{4}$ Del Río e Álvarez (2013) criticam o tratamento dado pela psicologia estadunidense e a tradução dos conceitos vigotskianos para o inglês, mencionando o alerta de Veresov (1998 apud DEL RÍO; ÁLVAREZ, 2013, p. 17-18) ao se traduzir soznanie (consciência, enquanto o tipo de operação psíquica que exige domínio e controle das funções voluntárias ou superiores) por mind (mente) e, também, psijica (todas as funções, incluindo as naturais, não voluntárias), usando a mesma palavra mind (mente). Segundo os autores, essa indistinção torna incompreensível o pensamento de Vigotski, e as teorias psicológicas acabam assumindo de forma geralmente implícita um duplo apriorismo: 1) o reducionismo das funções naturais a superiores (cognitivismo) ou das superiores a naturais (behaviorismo e algumas abordagens da psicologia evolucionista); 2) o pressuposto inatista das funções superiores, relegando os aspectos culturais a segundo plano.

5 Trecho da entrevista que segue esta apresentação.

${ }^{6}$ Conforme explicado por Pablo del Río, o termo "psicotecnia" é por ele utilizado como proposto por Vigotski: como o desenho de instrumentos psíquicos que a cultura emprega para mediar processos e construir as funções superiores.

${ }^{7}$ Conforme esclarecido por Pablo del Río a uma das autoras, durante visita à Fundación Infancia y Aprendizaje, em Madri, em fevereiro de 2020, o termo "desenho", do espanhol diseño, diz respeito ao desenvolvimento consciente de uma criação, em qualquer domínio, desde os princípios teóricos à sua execução prática.

8 Alexander V. Zaporozhets (1905-1981) foi um dos principais representantes da Escola de Cracóvia, tendo sido estudante e colaborador de Vigotski e Leontiev.
}

Práxis Educativa, Ponta Grossa, v. 17, e2219944, p. 1-24, 2022 Disponível em: <https://www.revistas2.uepg.br/index.php/praxiseducativa> 
mas colocou em relevo as funções diretivas, mais relacionadas com a moral, a vontade e a identidade. Em seu texto sobre o desenvolvimento e a construção da diretividade, Del Río e Álvarez (2006) comentam sobre a importância que têm adquirido para a história e a psicologia cultural, entre outras ciências que têm contribuído para a pedagogia, os "[...] problemas da direção da ação, os sentimentos, a formação do autocontrole e dos propósitos" (DEL RÍO; ÁLVAREZ, 2006 , p. 101, tradução nossa), para além da preocupação com os sistemas culturais de conhecimento e significado. Segundo os autores, recorre-se à obra de Vigotski mais para a investigação e compreensão dos mecanismos de sistemas culturais de significado e bem menos para se entender o que denominam "consciência diretiva"; e a "principal promessa" da obra do autor bielorrusso, ainda não realizada, seria "[...] sua capacidade de oferecer um lugar de encontro (de reencontro) às ciências humanas em que os aspectos cognitivos e diretivos estejam articulados no mesmo sistema explicativo" (DEL RÍO; ÁLVAREZ, 2006, p. 102, tradução nossa).

De acordo com sua análise, a teoria vigotskiana ajuda-nos a evitar quatro dos principais reducionismos da psicologia - redução ao racional, ao individual, ao interno e ao inato - que infelizmente seguem inspirando a maior parte dos desenhos curriculares ocidentais e as práticas escolares. Eles fazem uma ótima síntese das suas contribuições para combater esses reducionismos, mas nos atemos à primeira delas: "Frente à redução racionalista e sua ênfase exclusiva na transmissão do significado, Vygotski enfatizava a importância da construção cultural da emoção, o sentido e a diretividade" (DEL RÍO; ÁLVAREZ, 2006, p. 104, tradução nossa). Em sua explicação, as capacidades diretivas têm relação principalmente com as seguintes construções psíquicas ou funções superiores: emoção/ativação; exploração/orientação; decisão/intenção; conduta voluntária (autorregulação da ação); planificação, revisão, comprovação (autoexame cognitivo + moral-emocional). No entanto,

[...] esse conjunto de operações ou funções psíquicas são produto de mecanismos culturais historicamente desenvolvidos, e não temos nenhuma garantia, nem genética nem histórica, de que vão se manter e garantir um desenvolvimento adequado de cada criança e cada nova geração. Cada cultura produziu caixas de ferramentas diretivas mais ou menos próprias ou específicas. [...]. Gostaríamos de ressaltar aqui [...] que a diretividade se constrói a partir da emoção e da ação voluntária: dois aspectos um tanto menosprezados pela psicologia da última metade do século [XX]. (DEL RÍO; ÁLVAREZ, 2006, p. 106-107, grifos dos autores, tradução nossa).

A ênfase na emoção, por parte de Pablo Del Río, presente na entrevista e outros textos, vem, em parte, de sua formação marcada pela influência de seu mestre, René Zazzo ${ }^{9}$, por sua vez, discípulo de Henri Wallon, outro autor para quem a emoção é fundamental. Essa influência está registrada em um artigo da revista Enfance ${ }^{10}$, sobre a presença e o impacto da obra walloniana na psicologia evolutiva espanhola: "Em 1978, Pablo del Río publica um trabalho sobre a psicologia escolar e sobre a política educativa, muito próximo das ideias francesas da época. A revista Infancia y Aprendiraje, dirigida pelo infatigável Pablo del Río, publica igualmente nas suas páginas trabalhos que se inscrevem na mesma direção" (PALACIOS; VILA, 1993, p. 38-39, tradução nossa) ${ }^{11}$.

\footnotetext{
${ }^{9}$ Psicólogo francês (1910-1995) que atuou principalmente na área da Psicologia da criança. Discípulo e seguidor de Wallon no Hospital de Psicologia da Criança, realizou estudos sistemáticos sobre o desenvolvimento infantil, produzindo, por uma abordagem sócio-genética, instrumentos de diagnóstico para diversas idades, ao considerar a exposição das crianças aos conteúdos culturais. Zazzo investigou, especialmente, o desenvolvimento psíquico de gêmeos, o apego, o surgimento da imitação, a partir da hipótese de uma simbiose inicial, ou seja, da participação do outro no desenvolvimento do indivíduo (DEL RÍO; ÁLVAREZ, 2004).

10 Publicação de trabalhos sobre a infância, nas áreas de Psicologia e Educação, abarcando o desenvolvimento cognitivo, sensorial, motor, afetivo, social e de comunicação, criada por Wallon em 1948. O número ao qual nos referimos foi especial, em comemoração aos 30 anos de seu falecimento.

11 Os autores referem-se ao artigo Psicología escolar y política educativa, publicado no Cuadernos de Pedagogia, n. 41, p. 32-34.
}

Práxis Educativa, Ponta Grossa, v. 17, e2219944, p. 1-24, 2022 Disponível em: <https://www.revistas2.uepg.br/index.php/praxiseducativa > 
Para Pablo del Río, ambos - Wallon e Vigotski - contribuíram para a compreensão do funcionamento da emoção e consideraram a dimensão afetiva inseparável da dimensão cognitiva. Em um livro bastante conhecido do público brasileiro - Piaget, Vygotsky, W allon -, Marta Kohl de Oliveira, concordando com o que foi apontado por Del Río e Álvarez (2006), denuncia a separação entre essas dimensões ao longo da história da psicologia, assentada em uma divisão artificial e que, segundo a autora, acaba por fundamentar um entendimento fragmentado do funcionamento psíquico. A autora destaca que Vigotski nunca usou o termo "cognição", mas "funções mentais" (diríamos, a partir das novas traduções, "psíquicas") e "consciência" para designar processos tais como pensamento, memória, percepção e atenção, enfatizando a interrelação entre afeto e intelecto, assim como o caráter interfuncional, base para a abordagem do autor bielorrusso. Segundo ela, os pressupostos complementares dessa visão são: Em primeiro lugar, "[...] uma perspectiva declaradamente monista, que se opõe a qualquer cisão das dimensões humanas [...]. Em segundo lugar, uma abordagem holística, sistêmica, que se opõe ao atomismo [...] propondo a busca de unidades de análise que mantenham as propriedades da totalidade" (OLIVEIRA, 1992, p. 76, grifos da autora). Enfocando a mesma questão na perspectiva de Wallon, Heloysa Dantas afirma que nela a dimensão afetiva ocupa lugar central na construção do conhecimento e da pessoa, em um movimento dinâmico, complexo e paradoxal da atividade emocional que "[...] é simultaneamente social e biológica em sua natureza; realiza a transição entre o estado orgânico do ser e a sua etapa cognitiva, racional, que só pode ser atingida através da mediação cultural, isto é, social. [...] por outro lado, ao manter o seu caráter arcaico de tumulto orgânico, [...] ela manterá sempre, com a atividade reflexiva, uma relação de antagonismo [...]" (DANTAS, 1992, p. 85-86). A complexidade e a indissociabilidade dessa relação analisada pelos dois autores em várias de suas obras $^{12}$ e a extensa análise que vem sendo realizada por Pablo del Río e Amelia Álvarez sobre a relevância dessa consideração para a educação contrasta com a forma como a questão vem sendo colocada no Brasil por propostas como a da realização de avaliação das competências socioemocionais dos alunos e posterior trabalho nas escolas.

\begin{abstract}
Separar, para fins de mensuração, os aspectos socioemocionais dos aspectos cognitivos, isolando habilidades e traços de personalidade pré-definidos a partir de um construto tão questionado $[\mathrm{Big} f \mathrm{fiv}]$, tende a congelar e tipificar comportamentos, estabelecendo correlações que, mais uma vez, simplificam a complexidade e a dinâmica do desenvolvimento humano e ocultam as condições e contradições vivenciadas e enfrentadas por professores, alunos e seus familiares no cotidiano da instituição escolar. (SMOLKA et al., 2015, p. 236).
\end{abstract}

$\mathrm{Na}$ entrevista, que segue esta apresentação, Pablo del Río critica o modelo cognitivista e sua utilização da metáfora da mente humana como um computador, destacando que a razão não é um a priori, mas um resultado da síntese dialética entre ação e emoção - forma de tratar a questão enfatizada pelo autor, a partir das perspectivas vigotskiana e walloniana. Para ele, o centro do desenvolvimento é - portanto deve ser também o da educação - a atividade significativa, ou seja, a ação realizada com ativação emocional. A esse respeito ele discorre, exemplificando com situações e pesquisas que muito interessarão à prática docente e à pesquisa educacional. Com base em uma abordagem que une emoção, razão, sentido e ação, ele considera que é necessário um planejamento, um desenho educativo. Especificamente em relação à emoção e se reportando a Vigotski e Wallon, Del Río e Álvarez (2006, p. 107, tradução nossa) afirmam que "[...] a tese fundamental de ambos é que a emoção humana não é inatamente automática, e sim que ela se desenvolve e se educa, sendo, além disso, a base fundamental sobre a qual se constroem a identidade e a vida psíquica".

${ }^{12}$ Ver Vygotski (1999c), Vigotsky (2004) e Wallon (1995, 2007).

Práxis Educativa, Ponta Grossa, v. 17, e2219944, p. 1-24, 2022 Disponível em: <https://www.revistas2.uepg.br/index.php/praxiseducativa> 
Nesse sentido, é realçado o papel desempenhado pelas funções diretivas e, ao mesmo tempo, denunciado pelo entrevistado o seu esquecimento, em detrimento das consideradas cognitivas. A respeito da importância da diretividade, aspecto bastante enfatizado em vários de seus textos, Del Río e Álvarez (2007a) explicam:

\begin{abstract}
Nos experimentos desenvolvidos por Luria e seus colegas (Luria, 1978) sobre a gênese da ação executora, forneciam-se às crianças mediações verbais, sociais e instrumentais. Esses mediadores permitiram às crianças controlar sua própria ação e dirigir seu próprio comportamento indiretamente, isto é, re-dirigir suas ações. Essa diretividade ou rediretividade mediada, caracteristicamente humana, por meio da qual - como Vygotsky $(1926 / 1982 / 1990)$ diria - seres humanos condicionam a si mesmos para se liberar das prescrições diretas dos estímulos do meio, é o que geralmente vem a ser chamado diretividade na tradição histórico-cultural. Portanto, a ação direta involuntária se desenvolve em ação voluntária indireta e autocontrolada. (DEL RÍO; ÁLVAREZ, 2007a, p. 375, tradução nossa).
\end{abstract}

No mesmo texto, os autores mencionam uma observação de Zinchenko ${ }^{13}$ de que a pesquisa histórico-cultural praticamente ignorou a "arquitetura cultural diretiva", relacionada às "psicotecnias dos sentimentos" que o entrevistado considera, com Vigotski, tão importantes quanto as "psicotecnias do intelecto". E o mais triste: ele afirma que "a escola se esqueceu de ambas".

Os inúmeros projetos de investigação inspirados na Fundação Infância e Aprendizagem ${ }^{14}$ representam uma importante empreitada tanto teórico-metodológica quanto prática, relacionando a questão das funções diretivas e a necessidade de se traçar uma "dieta cultural" para as novas gerações. Estes são alguns dos problemas investigados: “[...] a dieta audiovisual e seu papel na construção da realidade e do imáginário; a importância dos contextos de desenvolvimento e das atividades infantis para a construção da atenção; os efeitos da dieta televisiva sobre o desenvolvimento infantil e juvenil, especialmente em relação a problemas de atenção; os meios de comunicação e a construção de identidades culturais" (DEL RÍO; REGO; BRAGA, 2013, p. 514). Em seu Informe sobre el impacto de la televisión en la infancia, Del Río, Álvarez e Del Río (2004) analisam o impacto genético-cultural da televisão sobre as crianças e expõem problemas causados pelas condições atuais de produção, uso e recepção desse meio de comunicação, por meio de uma análise funcional (em termos do desenvolvimento da atenção, percepção, imaginação, identidade, moral, etc.), bem como o impacto na vida cotidiana, mas também propõem um desenho estratégico de alternativas, com um conjunto de orientações e de propostas.

Para além da constituição do sistema funcional ${ }^{15}$, Pablo del Río relaciona a questão do desenho cultural e educativo com o problema da falta e da necessidade da existência de "narrativas constituintes de identidade" que ele percebe nos jovens da Espanha e que podemos estender à realidade brasileira, talvez ainda mais preocupante. De forma apaixonada, ele fala das duas "ecologias" em que vivemos, a "situada" (construída continuamente nos usos de instrumentos, práticas e ritos) e a "imaginada" (construída nas "narrativas, nos contos, nas novelas, parábolas,

\footnotetext{
13 Vladimir Zinchenko (1931-2014) formou-se no Departamento de Psicologia da Universidade Estadual de Moscou, defendendo tese de Doutorado sobre ação e percepção em 1966. Desenvolveu importantes trabalhos relacionados à ergonomia, à técnica e à estética. Foi membro fundador e chefe do Departamento de Psicologia na Dubna State University for Nature, Society and Mankind e importante teórico da Teoria Histórico-Cultural. Em 2005, liderou a criação do periódico Psicologia Histórico-Cultural publicado pela Universidade Estadual de Psicologia de Moscou. Desde então, até seu falecimento, permaneceu como editor-chefe da revista.

14 Descritos em Del Río, Rego e Braga (2013).

15 Segundo Luria (1992), o termo foi introduzido formalmente por P. K. Anokhin, por volta de 1935, mas o grupo soviético já vinha trabalhando com essa noção bem explicitada em textos como Sobre os sistemas psicológicos e O problema da consciência (VIGOTSKI, 1996).
}

Práxis Educativa, Ponta Grossa, v. 17, e2219944, p. 1-24, 2022 Disponível em: <https://www.revistas2.uepg.br/index.php/praxiseducativa > 
filmes, séries") e busca em seu filósofo predileto - Miguel de Unamuno ${ }^{16}$ - elementos para inspiração e discussão. Um desses elementos é a necessidade de se escreverem três novelas: "a novela da pessoa, a novela do país, a novela da humanidade". Isso implica a construção de um personagem e um mundo simbólico, por parte da criança ou do jovem, para si mesmos. E nós, adultos e educadores, temos de possibilitar tal construção. Um outro elemento está contido, por exemplo, no título de uma de suas obras, Del sentimiento trágico de la vida (UNAMUNO, 2017). De acordo com o escritor e estudioso de Unamuno, bem como de outros autores espanhóis, que apresenta esse texto do filósofo,

[o] centro da filosofia de Unamuno, o objeto de sua investigação, e seu ponto de partida, [...] é o "homem concreto", o homem de "carne e osso". Ou seja, parte da situação em que se encontra o ser humano consciente que contempla com inquietude seu destino. Refere-se a qualquer homem; embora, é claro, refira-se muito especialmente àquele que tem mais à mão e conhece melhor, ou seja, a si mesmo. (SÁNCHEZ-BARBUDO, 2017, p. 19, tradução nossa).

No texto De la psicología del drama al drama de la psicología. La relación entre la vida y la obra de Lev S. Vygotski, é explorada a questão fundamental colocada tanto por Unamuno quanto por Vigotski da vida humana como tragédia e do sentido da vida como sentimento trágico, no caso do segundo, em sua análise de Hamlet (VIGOTSKI, 1999b) e na Psicologia da Arte (VIGOTSKI, 1999c). Segundo Del Río e Álvarez (2007b), Vigotski compartilhava a ideia de Espinosa de que o determinismo no ser humano deve converter-se em determinação, e ela foi base para a sua investigação (e de Luria) sobre o ato voluntário e a função executora:

Vygotsky também acreditava que, em sua lógica final, o homem dotado de autodeterminação é necessariamente trágico e deve enfrentar o sofrimento e inevitavelmente, em algum momento, a sua morte, sobrepondo-se à reação natural que impede a percepção desta, ou à reação de fuga e esquecimento dessa condição quando, graças à consciência, consegue percebê-la. (DEL RÍO; ÁLVAREZ, 2007b, p. 305, tradução nossa).

Em suas análises do conceito, os autores relacionam o drama psíquico (POLITZER, 2004; VIGOTSKI, 2000a) à literatura e ao teatro, aos personagens que vão fazendo parte (fundamental) de nossa existência.

[...] independentemente de que o narrado e exposto em uma determinada obra de teatro, uma fábula, uma novela ou uma parábola não possuam a realidade da história, possuem realidade histórica, pois seguem atuando sobre a psiquê humana ao longo de gerações. Recordemos a esse respeito a tese de Unamuno (1987a, 1987b), que atribuía mais realidade histórica a Dom Quixote do que a Cervantes, na medida em que as façanhas do cavaleiro mantêm sua influência através dos séculos, e a figura e a vida do cavaleiro fictício constituem um modelo mais vivo do que a vida passada real de Cervantes. (DEL RÍO; ÁLVAREZ, 2007b, p. 320, tradução nossa).

Trazendo para nossa realidade - vivencial, social, política, educacional... - da pandemia hoje, de adoecimento e morte, e pensando no drama (intensificado) dos/as professores/as e alunos/as, nos sentidos da experiência de isolamento (ou de retorno sem as condições adequadas das escolas), buscamos, na problematização de Carvalho (2020), a partir de autores como Ricoeur e Arendt, sobre o "esvaziamento da dimensão temporal" que agudiza a "crise da educação", um diálogo com as palavras anteriores, de Del Río e Álvarez (2007b).

${ }^{16}$ Filósofo espanhol (1864-1936) que sugeriu um modelo narrativo da vida humana: do ler-se e escrever-se como novela, como um instrumento cultural para apropriar-se da própria vida.

Práxis Educativa, Ponta Grossa, v. 17, e2219944, p. 1-24, 2022 Disponível em: <https://www.revistas2.uepg.br/index.php/praxiseducativa> 
Nos romances de Garcia Márquez ou de Camus; nos quadros de Egon Schiele ou de Munch, nas obras de Shakespeare ou de Ingmar Bergman encontramos diferentes formas de refiguração artística das dores, dos temores e do isolamento enfrentados em face das ameaças de uma epidemia; assim como travamos contato com a grandeza e a coragem de homens e mulheres - reais ou fictícios - que fazem desse incidente uma oportunidade para a afirmação da dignidade da ação humana (como Dr. Rieux, o protagonista da obra de Camus, $A$ Peste). (CARVALHO, 2020, p. 10-11).

Convidamos, então, à leitura da segunda parte da entrevista, após as referências, em que o autor nos brinda com palavras lúcidas, entusiasmadas e necessárias. Como o leitor poderá constatar, o conjunto de temas explorados por Del Río expressa o mosaico de dimensões implicadas na formação do indivíduo contemporâneo. Nele se observa a preocupação do pesquisador com os processos de construção de conhecimento, as possibilidades de protagonismo dos alunos, bem como com a organização de contextos favoráveis à emergência de práticas significativas de ensino e aprendizagem. A originalidade de sua argumentação, a consistência de suas análises e, sobretudo, a atualidade dos problemas que enfrenta, representam uma criativa interlocução com todos aqueles interessados em projetar novas formas para a instituição escolar, para suas práticas e seus currículos.

\section{Entrevista com Pablo del Río}

Entrevistadoras: Gostariamos de lhe pedir que falasse um pouco sobre as implicações de seu campo de pesquisa e de estudo para a educação. Para iniciar, qual seria, na perspectiva vigotskiana, o papel da educação e da escola no desenvolvimento humano?

Pablo del Río: Na abordagem vigotskiana, a educação engloba todo o desenvolvimento da criança e do sistema de funções superiores humanas. Talvez seja adequado recordar que, na nossa perspectiva, a mente humana bem desenvolvida não está garantida pela herança; continua sendo uma experiência evolutiva frágil, que deve se repetir em cada pessoa e em cada cultura. Os genes asseguram a base do edifício funcional neurológico, mas não a construção das chamadas funções superiores, que somente se alcança de maneira adequada se a cultura e a educação cumprem bem seu compromisso. Ou seja, o fato humano não está garantido pelos genes, nem pela cultura, mas pelos genes e a cultura conjuntamente. A espécie humana é, pois, uma espécie condenada continuamente à evolução, obrigada ecoevolutivamente à educação. A partir da perspectiva vigotskiana, Davydov ${ }^{17}$ cunhou um termo que define bem essa educação orientada a construir o edifício das funções superiores: "educação desenvolvimental" psicológicas uma a uma: ensinar a perceber, atender, recordar, pensar, raciocinar, sentir, comportarse moralmente, construir a vontade, a identidade...

A teoria de Vigotski explica e demonstra experimentalmente como se constroem as funções por meio de mediações instrumentais e sociais. Se revertermos essa teoria para aplicá-la para o desenho educativo temos um guia muito poderoso para fundamentar solidamente o trabalho pedagógico. Enquanto as funções superiores se constroem mediante a mediação instrumental e social, para fazê-lo bem é preciso recorrer a uma "engenharia psicológica" que, em nossa perspectiva, é engenharia cultural, desenho cultural' ${ }^{19}$.

\footnotetext{
${ }_{17}$ Psicólogo russo (1930-1998) do Departamento de Psicologia da Faculdade de Filosofia da Universidade Estadual de Moscou. Trabalhou no campo da psicologia pedagógica e da didática. Dentre suas principais contribuições, destaca-se a formulação da teoria do "ensino desenvolvimental". Para mais informações sobre sua vida e obra, consultar Libâneo e Freitas (2013).

${ }^{18}$ No original, "educación desarrollante".

19 O termo "desenho" é traduzido do original “diseño", por recomendação do entrevistado.
}

Práxis Educativa, Ponta Grossa, v. 17, e2219944, p. 1-24, 2022 Disponível em: < https://www.revistas2.uepg.br/index.php/praxiseducativa $>$ 
Pablo del Río, Elizabeth dos Santos Braga, Teresa Cristina Rego e Ana Luiza Bustamante Smolka

Creio que seria necessário recuperar o experimento formativo, e as psicotecnias $^{20}$ vigotskianas, tão pouco conhecidas. Apesar da divulgação da teoria desse autor e de certos conceitos gerais, conhecese comparativamente menos o rico filão de aplicações e instrumentos psicológicos para o desenvolvimento e a aprendizagem.

Entrevistadoras: Você poderia falar um pouco mais dessa questão do uso de psicotecnias on instrumentos na educação (ou no ensino)?

Pablo del Río: Os professores geralmente encontram-se despreparados para o ensino do cálculo, da geometria, da álgebra, da física, da moral, do raciocínio, da arte... E, no entanto, o desenvolvimento de psicotecnias para a educação é um método de possibilidades infinitas. Em meu primeiro experimento formativo, apliquei o desenho de psicotecnias para o ensino de geometria. Trabalhei com crianças de um centro que não demonstravam certos conhecimentos, e elas terminaram incorporando externa e internamente o uso de instrumentos psicológicos que planejamos para controlar a distância, a orientação, a perspectiva, etc. Davidov, a quem acabo de citar, desenvolveu instrumentos para o ensino da álgebra dentro de sua perspectiva de desenvolver de maneira concreta o que chamamos "pensamento teórico", e um grupo variado de investigadores russos, na trajetória de Vigotski ou de Galperin, desenvolveu recursos e mediações diversas. Podemos fazer isso não somente com relação às funções intelectuais ou cognitivas, mas também em relação às funções diretivas mais relacionadas com a moral, as emoções, a vontade ou a identidade.

É possível que a falta de perspectiva histórica e cultural do desenvolvimento humano tenha a ver com essa invisibilidade dos instrumentos culturais que permitiram à humanidade chegar até aqui e que permitem a cada novo ser humano, a cada criança, fazer a viagem até a formação de uma mente plena. Se Copérnico necessitou de uma esfera armilar para conceber a órbita, ou Euclides uma corda esticada para conceber a reta, se os hindus necessitaram do ábaco para calcular e conceber o número negativo, por que pensamos que a criança poderá realizar todas essas façanhas simplesmente com palavras e explicações verbais? As mediações instrumentais e sociais são invisíveis para a psicologia não vigotskiana, e não passam de referentes conceituais para a maioria dos que conhecem a perspectiva de Vigotski. Aplicá-la à educação supõe uma revolução da prática no desenho educativo. Se faço essa reflexão sobre a lacuna instrumental nos sistemas educativos atuais é para recolocar as prioridades do desenho educativo, pois, hoje, não se planejam os currículos pensando na caixa de ferramentas funcionais para a vida da criança, mais tarde do adulto.

Entrevistadoras: Além da "lacuna instrumental", quais são, em sua opinião, outros graves problemas ou lacunas que enfrentamos hoje no campo da educação?

Pablo del Río: Existe uma outra lacuna preocupante nos sistemas educativos atuais: a da atividade. $\mathrm{Na}$ medicina, investigam-se os sérios transtornos do sedentarismo infantil e escolar no plano do desenvolvimento físico (diabetes, obesidade, transtornos diversos), mas eles são pelo menos tão relevantes quanto os transtornos do desenvolvimento psíquico. O desenvolvimento do cérebro e do sistema psicológico em geral se produz por meio da atividade, e os contextos culturais do

\footnotetext{
20 "Empregamos o termo psicotecnia tal como o propõe Vygotski, como o desenho de instrumentos psicológicos externos que a cultura emprega para mediar processos e construir assim as funções superiores internas: a arqueologia de toda função superior remete a estas psicotecnias: operadores instrumentais externos e operações socialmente compartilhadas." [Nota do entrevistado].
}

Práxis Educativa, Ponta Grossa, v. 17, e2219944, p. 1-24, 2022 Disponível em: < https://www.revistas2.uepg.br/index.php/praxiseducativa > 
desenvolvimento da criança apresentam uma crescente lacuna a esse respeito. Além disso, a atividade tem de ter sentido, finalidade, resultados visíveis e desejáveis para a criança.

Associado ao vazio de atividade significativa, quero assinalar outro problema na educação atual que procede de se pensar mais no conhecimento do que na criança. Para a perspectiva ecobiofuncionalista, que inclui, mas não se limita à vigotskiana, a educação tem como objetivo o desenvolvimento do organismo humano, e a aprendizagem não é outra coisa que a aquisição de capacidades para atuar, para viver. O essencial na educação não é, pois, que a criança carregue um corpus de conhecimento acumulado pelas disciplinas, mas que incorpore todo um complexo de instrumentos, capacidades e modos de perceber e sentir que lhe permita reconstruir-se como pessoa e desenvolver suas funções para viver de modo mais pleno. Em todos os sentidos: intelectual, moral e emocional. O processo educativo não se dirige para o conhecimento, mas para a vida, e o protagonismo não se situa no currículo (embora encapsular e listar ações sejam sempre mais atraentes para os sistemas institucionais). O protagonismo está na criança e no educador.

Se aprendemos algo e não o usamos, nos esquecemos; aquilo se perde. Além disso, não vemos o sentido de aprendê-lo, pois não o fazemos por meio da atividade nem para a atividade. Há um desencontro entre o currículo da vida e o das instituições educativas. Nesse sentido, nos encontramos hoje com muitos analfabetismos funcionais, não só o da leitura e da escrita, mas o de muitos conhecimentos curriculares: o que se aprende na escola e não se usa, como não ocupa nenhuma função vital, morre. Seria necessário repensar os conteúdos educativos de maneira funcional, desenhando seu programa a partir da vida e desenhando seu domínio mediante o domínio das mediações.

Entrevistadoras: E quais seriam, na sua opinião, os instrumentos e as capacidades necessários para a vida contemporânea?

Pablo del Río: Há cem, cinquenta anos, existia um modelo de atividade produtiva e uma estrutura social e cultural distintos dos que temos hoje. Atualmente, uma grande parte dos adultos tem ficado desprovida de atividades vitais produtivas (de trabalho, de atividade doméstica). Uma parcela ainda maior de jovens encontra-se parada, à medida que as sociedades viajam em direção a um futuro inquietante de sociedades de consumo, armadas sobre a globalização de grandes corporações que produzem trabalho e atividade apenas para uma pequena parcela da população. Na Europa, as taxas de desemprego são altas; na Espanha, durante a crise econômica de 2008, o desemprego juvenil subiu até os 50\%; na Grécia, 60\%, embora atualmente tenha havido um decréscimo, há, ainda assim, cifras preocupantes. Estamos condenados a sociedades deficitárias de atividade, exceto a atividade de lazer e de consumo. As megalópoles, onde se concentra a maior porcentagem, continuamente crescente, de população mundial, são estruturalmente deficitárias de atividade produtiva e de conexão com a natureza. E, no entanto, a perspectiva vigotskiana nos diz claramente uma coisa: para produzir o desenvolvimento funcional e pessoal, o ser humano precisa de esforço e trabalho. Inevitavelmente, a reflexão e a reorientação educativa nos obrigam a voltar a olhar a vida e a estrutura das sociedades e das culturas. E aí encontramos graves problemas, que se convertem em desafios enormes para a educação nos dias de hoje.

Sem nos darmos conta, a ilusão de uma sociedade e uma educação em busca da informação e do conhecimento, e não de vida e de realidade, tem convertido nossos currículos em tratados volumosos, cheios de peso morto e carentes de sentido para os estudantes e de significado para a vida. Cada vez há mais alunos que sentem depressão ao pensar em assistir às aulas, sofrendo de um alto desinteresse educativo, para o que educadores e psicólogos tentam encontrar uma raiz psicopatológica. No entanto, a patologia é cultural: está nos marcos culturais; está na vida; está na escola.

Práxis Educativa, Ponta Grossa, v. 17, e2219944, p. 1-24, 2022 Disponível em: < https://www.revistas2.uepg.br/index.php/praxiseducativa $>$ 
$\mathrm{Na}$ época de Vigotski, a distinção entre inteligência prática e inteligência teórica estava não somente muito presente na investigação dos psicólogos teóricos, mas também na aproximação com a educação. Todos necessitamos de inteligência prática para a vida. E, certamente, aqueles que têm acesso à universidade e ao conhecimento científico ou humanístico precisam de inteligência teórica. A educação atual produz um híbrido estranho que não é nem inteligência prática nem inteligência teórica. Por isso, Perkins tem caracterizado uma grande parte dos novos alunos com o que denomina "pensamento débil e conhecimento frágill". Trata-se de conhecimentos que não são nem práticos nem teóricos, mas que mimetizam verbalmente o conceitual.

Mais uma vez, falta aqui uma análise das caixas de ferramentas da mente cultural (as mediações instrumentais e as mediações sociais ou procedimentos e ritos) com que se constroem as competências da inteligência prática ou as do pensamento teórico, termo empregado por Davydov.

Com esse panorama, é difícil pensar que professores e alunos cheguem com paixão à escola e saiam dela como pessoas aguerridas, dispostas a enfrentar a vida com confiança.

Entrevistadora: A partir do que falou acerca do desinteresse pelo conbecimento por parte dos alunos, da falta de paixão de alunos e de professores, pensamos que as práticas educativas quase sempre tratam de modo separado (e até antagônico) os aspectos relacionados à razão e à emoção, não é?

Pablo del Río: Com certeza. Há uma frase de Vigotski em que ele diz que todo momento de profunda mudança cognitiva coincide com um momento de profunda alteração emocional. De um lado, ele é muito racionalista, busca a arquitetura dos operadores, da mediação, dos processos intelectuais; mas, por outro lado, ele sempre continua buscando o sentido e a conexão com a vida e a psicologia concreta. E é a emoção que conecta esses processos.

A psicologia de Vigotski que tem se divulgado na educação parte do modelo da mediação postulado em suas obras centrais sobre o desenvolvimento das funções psicológicas superiores. É um modelo desenvolvido a partir do modelo clássico estímulo-resposta e que se articula bastante bem com a psicologia dos processos intelectuais ou racionais. Entretanto, em sua etapa final, quando Vigotski abre o caminho para a neurologia, ele parte de outro modelo em que toma a unidade básica de psicólogos como Köhler, Koffka e Lewin que, por sua vez, o herdaram do modelo ecofuncionalista de von Uexküll ${ }^{21}$, que postulava o ciclo percep̧̧ão-ação. Vigotski, então, recoloca seu modelo das funções psíquicas superiores com base na unidade de percepção-ação-afeto, o que nos leva a compreender melhor a criança como um ser vivo e seu desenvolvimento como algo mais próximo a uma psicologia concreta. Uma verdade na neuropsicologia atual, afinada com essa proposta última de Vigotski, é que não há neurogênese (desenvolvimento de novos neurônios) ${ }^{22}$, se não se ativam os campos motores e emocionais. A criança não muda, não aprende, não se desenvolve, sem uma ativação e um papel central da ação e da emoção. O canal central do desenvolvimento - e, portanto, deve ser o da educação - é a atividade significativa, a ação realizada com ativação emocional. Contudo, nos sistemas educativos que têm partido dos paradigmas do conhecimento como processamento, é difícil de se conectar com essa perspectiva, que é a dos seres vivos em desenvolvimento.

Quando estávamos fazendo investigações sobre os desenhos animados, sobre a estrutura da atenção e a estrutura cognitiva das crianças, analisamos um modelo em psicologia da persuasão

\footnotetext{
${ }^{21}$ Biólogo estoniano (1864-1944) que, da perspectiva da ecologia, propôs o "círculo funcional” de interação (cibernética e dialética) entre organismo e meio.

22 Para uma melhor compreensão do termo, sugerimos a leitura da primeira parte da entrevista com Pablo del Río, publicada na Educação e Pesquisa, v. 39, n. 2, 2013.
}

Práxis Educativa, Ponta Grossa, v. 17, e2219944, p. 1-24, 2022 Disponível em: <https://www.revistas2.uepg.br/index.php/praxiseducativa> 
em publicidade e em comunicação de massas, o de Petty e Cacioppo. ${ }^{23}$ Eles propõem a existência de uma rota central e uma periférica no processamento dos materiais culturais da vida cotidiana, sobretudo os de televisão. A persuasão se produz na rota central; as outras são as imagens, as percepções, as emoções, como se tudo o que não é razão fosse algo de uma classificação cognitivamente inferior, periférico. Ou seja, central é o consciente, periférico é o inconsciente; central é o verbal, periférico é o não verbal; central é a razão, periférico é a emoção.

Ao contrário, no modelo neuropsicológico de Vigotski, não pode haver rota central sem emoção e ação, e os próprios processos racionais resultam superficiais ou forçados se se desvinculam desses processos importantes. Se você revisa a Psicologia da Arte ${ }^{24}$, a tese que Vigotski propõe é que a arte (a tragédia, por exemplo) é a maneira de manter o fato cognitivo e o fato emocional ativados ao mesmo tempo, mediante o que ele chama de enfrentamento e suspensão dos contrários. Você está com Romeu e Julieta ou com Hamlet e fica continuamente pensando, sentindo: "vai acontecer algo". Esse enfrentamento se mantém até o final, quando se produz uma ruptura, e razão e emoção se juntam. Produz-se a reestruturação. No modelo de Vigotski, tanto o racional como o emocional são centrais e o são porque caminham juntos. A imagem e a palavra não são por si mesmas centrais, senão na medida em que sejam capazes de envolver o sujeito e sua atividade. Ou seja, o modelo de Petty e Cacioppo não explica o que acontece na arte, divide-a em duas partes, e a força se perde. E, como eu acredito que a educação é uma arte, não explica tampouco o que acontece na aprendizagem, no desenvolvimento, na boa educação.

\section{Entrevistadoras: A propósito, o que você considera uma "boa educação"?}

Pablo del Río: Na boa educação, deve-se produzir uma paixão na criança pelo que ela está fazendo, uma implicação emocional que deve acontecer por meio de um processo racional. No sistema de experimento formativo dos mediadores cognitivos, na nossa investigação sobre geometria a que me referi anteriormente, fizemos o seguinte: quando a criança utilizava um artefato instrumental, era levada a fazê-lo em grupo (significação compartilhada) e, efetivamente, nosso desenho da atividade requeria que o instrumento mediador fosse utilizado em parceria com outra criança. Assim, por um lado, as atividades instrumentais eram sempre compartilhadas; e, por outro lado, as atividades sociais, ao se instrumentalizarem, convertiam-se em racionais. Esse duplo processo funciona muito bem. Em boa parte das explicações sobre a zona de desenvolvimento proximal, somente se fala de mediação social, nunca dos artefatos que medeiam o desenvolvimento. Não se trata de uma escolha entre a escola voltada para o tecnológico ou social, racional ou emocional: deve-se fazer as duas coisas ao mesmo tempo com projetos carregados de significado e de sentido - essa é a arte de ensinar.

Se há uma teoria psicológica intrinsecamente tecnológica, inclusive mais que a [teoria] cognitiva, é a histórico-cultural, a vigotskiana. A cognitiva, ao supor que os processos mentais são racionais e lógicos (trazendo a metáfora de mente como computador), toma a tecnologia como modelo, porém não compreende seu papel como mediadora funcional de um organismo vivo guiado pela ação e pela emoção. A perspectiva cognitiva supõe as funções superiores como capacidades internas. Consequentemente, a única coisa sobre a qual se atua no campo educativo são as estratégias de usá-las por meio de uma tecnologia ou de outra. Paradoxalmente, a teoria

\footnotetext{
${ }^{23}$ Para mais explicações, ver http://www.acrwebsite.org/search/view-conference-proceedings.aspx?Id=9252. Acesso em: 27 out. 2021.

24 Tese doutoral de Vigotski, não defendida, mas aprovada em 1925. Publicada no Brasil pela Martins Fontes, com tradução direta do russo feita por Paulo Bezerra (VYGOTSKI, 1999c).
}

Práxis Educativa, Ponta Grossa, v. 17, e2219944, p. 1-24, 2022 Disponível em: <https://www.revistas2.uepg.br/index.php/praxiseducativa > 
Pablo del Río, Elizabeth dos Santos Braga, Teresa Cristina Rego e Ana Luiza Bustamante Smolka

histórico-cultural é mais técnica na sua compreensão do papel psicológico dos instrumentos e das tecnologias. A tecnologia e a razão se incorporam à nossa natureza, mas a partir da cultura.

O perigo para a educação é que, com o paradigma cognitivo, adotou-se uma visão computacional da mente humana. Pensa-se no aluno como um computador que aprende, uma tecnologia que processa, não um ser vivo que usa instrumentos para viver. Existem tecnologias nas duas abordagens, mas o significado é diferente. A partir do racionalismo cognitivo, tende-se a assumir que o ser humano é antes de tudo racional. No nosso ponto de vista, o desenvolvimento parte do organismo vivo que se move, a partir da unidade básica percepção-ação-afeto. Chegamos (ou não) ao conhecimento racional e à lógica a partir da ação/emoção. $\mathrm{Na}$ perspectiva de Vigotski e também na minha, o aluno é um ser vivo, e um ser vivo somente se move por emoções.

O cursor, o guia de orientação dos seres vivos é a emoção, diz Wallon. E Vigotski concorda com isso, sobretudo em certas etapas de seu trabalho mais que em outras; em etapas como a das funções superiores ele se volta muito para o intelectual, mas há outros momentos em que ele retorna ao sentido. Sobretudo na etapa final, quando ele postula o trabalho dos três blocos neuropsicológicos desse sentido, ou seja, o sentido se baseia no afeto, na percepção da situação e no movimento e está definindo o que logo Luria vai encontrar como os três blocos fundamentais do cérebro humano. Nesse sentido, o que ocorre? O organismo vivo - e a criança o é - necessita mover-se todo ao mesmo tempo; não podemos movê-lo em pedaços. Não posso mover sua razão por um lado, sua emoção por outro, sem ao mesmo tempo considerar que se trata de uma situação. Então, isso marca princípios muito básicos na educação: ela tem de passar por atividades significativas.

\section{Entrevistadoras: E como seria a apreensão pela educação desses princípios que relacionam emoção, ação e intelecto?}

Pablo del Río: As atividades na primeira infância se fazem significativas porque são os outros que são significativos, e tudo o que eu faço com a pessoa que amo é significativo; e logo a significação vai se transferindo para as emoções e as ações; assim, o salto aos operadores vai se transferindo para os próprios instrumentos e, de repente, a escrita para você se converte numa coisa prazerosa, ou usar o computador ou o celular. Vamos atribuindo emoções às coisas e ao mundo que nos rodeia. As funções diretivas superiores humanas (a moral, a vontade, a atenção voluntária, a decisão racional, a identidade, o projeto de vida como narrativa, etc.), as construímos com psicotecnias culturais como a poesia, a tragédia, a parábola, ou até mesmo o Pai Nosso. Nem as funções diretivas são menos importantes que as cognitivas, nem as psicotecnias do sentimento ou da moral são menos necessárias do que o raciocínio ou o cálculo. Se o ábaco ou a tabela de multiplicar me permitem mediar e construir o cálculo mental e a aritmética, as parábolas, a tragédia, a religião ou a poesia me permitem reconstruir as emoções em sentimentos. Tão importantes quanto as psicotecnias do intelecto, como chamava Vigotski, são (talvez até ainda mais) as psicotecnias do sentimento - emprego também o termo de Vigotski. E a escola se esqueceu de ambas.

A escola emprega instrumentos psicológicos e psicotecnias de uso geral da cultura que, como tais, se tornaram invisíveis aos nossos olhos como a água é invisível para os peixes: não vemos o papel psicotécnico do sino, do semáforo, dos sinais de trânsito, ou das linhas no caderno de escrever... Todavia, a escola deveria ser mestra e especialista no desenho e no manejo das psicotecnias que a criança precisa para seu desenvolvimento.

No campo do desenvolvimento diretivo da moral e das emoções, antes se fazia intuitivamente, por exemplo, em todos os rituais religiosos, com a leitura das parábolas do evangelho, com a evocação da mente social divina compartilhada. Quando a avó dizia à criança: "Ah, o Menino Jesus vai ficar triste se você tirar a bola do amiguinho...", e a criança dizia à avó:

Práxis Educativa, Ponta Grossa, v. 17, e2219944, p. 1-24, 2022 Disponível em: < https://www.revistas2.uepg.br/index.php/praxiseducativa $>$ 
“Aqui está”; funcionava! Funciona! São neurônios de espelho; é o contágio emocional e social. E, de repente, a criança vê a outra criança, porque não a estava vendo; estava vendo somente a bola. Então, todas essas técnicas primitivas de ativação da emoção e de vinculação da emoção à atividade foram esquecidas. Não quero dizer que devemos usar as primitivas, mas, sim, que usemos alguma. E o jogo protagonizado, as marionetes, o teatro, as atividades coletivas, o esporte são atividades com realização funcional25. Porque a criança, o ser humano, se guia e se mobiliza pela ação, não pela lógica ou conhecimento. Nós não podemos nos desenvolver baseados em "lições", mas em ações significativas. A diferença de uma operação com sentido e uma sem ele é que a primeira produz um efeito que justifica a ação, tem o que chamamos de realização funcional. Minha professora primária nos ensinava química usando um alambique, mas o momento final era quando nós bebíamos o licor que havíamos produzido com o experimento. A realização funcional satisfaz a unidade básica percepção-ação-afeto. Lembro-me que, quando era criança, para mim, o fato de ir semear, colher, levar o trigo à carroça ou à esteira e, depois, moê-lo, manusear a máquina de moer, ver sair o trigo e pegá-lo era uma coisa tão telúrica, profunda, gratificante, porque todas as atividades desse ciclo tinham realização funcional. E, então, você vincula o conhecimento técnico que está adquirindo: como você tem que pegar a foice para ceifar, ou como tem que usar a manivela da máquina de moer (quando eram manuais). Por que eu aprenderia psicomotricidade no vazio? Por que não posso fazer algo significativo?

Entrevistadoras: Nesse sentido, você crê que a escola tem deixado a desejar a atividade, o sentido e o significado, os próprios processos de como as coisas acontecem? É tudo muito abstrato para a criança e há uma carga excessiva de conteúdos no currículo, em vez. de ser algo significativo e que realmente leve à criança à ação, tal como apontado pelo movimento da chamada "escola renovada", não é?

Pablo del Río: Sem dúvida, essa questão já estava em boa parte dos movimentos educativos renovadores de princípios do século XX e em muitos outros que continuam surgindo agora. Há gente que está fazendo o correto, a partir de ideias que vêm de todo lugar e, nesse sentido, é preciso ter abertura porque na educação acontece como acontece na medicina. Diante de uma criança, um homem ou mulher com um problema, o conhecimento teórico e metodológico de um bom clínico pode não ser suficiente. Pode ser que nenhuma das teorias ou dos avanços científicos atuais lhe permita curar ou ter uma solução para o caso, e o clínico, apesar de tudo, trabalha. Há, assim, uma parte de arte. O clínico não pode se permitir ser ortodoxo; é eclético sempre - eclético no bom sentido, não no de sincrético -, usa tudo o que, neste momento, lhe permitir tomar decisões. Com os recursos disponíveis, tem de fazer o que faz como um bom artesão. Numa caixa de ferramentas, podem faltar ferramentas, mas, se é preciso fazer uma mesa, faz-se a mesa. Se não for feita de uma maneira, faz-se de outro material, porque a atividade manda. Então, na medicina clínica e na educação, acontece o mesmo. Desse modo, a educação tem de ser eclética também, tem-se de usar todas as teorias. Não temos de impor uma ortodoxia aos educadores. Isto é, não temos apenas que dar teoria vigotskiana aos educadores, mas também metodologia vigotskiana, maneiras de fazer as coisas que lhes resolvam problemas. Por exemplo, as matemáticas estão funcionando muito mal. Em que âmbitos? Cálculo, aritmética, geometria, álgebra? Bom, vamos buscar desenhos de mediação, experimentos formativos, com objetos, artefatos mediadores, com atividades significativas e, daí, levar à escola. Não posso dar-lhes somente teorias de Vigotski e, aí, há uma lacuna. Boa parte dos problemas que temos na perspectiva histórico-cultural são merecidos porque não se desenvolveram tanto instrumentos; houve um desenvolvimento metodológico, empírico e aplicado deficiente. Temos de desenvolver instrumentos. Acontece o mesmo quando você toma qualquer outra parte do currículo. O desenvolvimento moral, educação física, saúde, ciências físicas; qualquer aspecto

\footnotetext{
${ }^{25}$ No original, "cierre funcional". Segundo o entrevistado, o sentido seria de "culminação" ou "realização", ou seja, "uma
} ação que cumpre a sua expectativa e o seu objetivo, tem um resultado, um final”.

Práxis Educativa, Ponta Grossa, v. 17, e2219944, p. 1-24, 2022 Disponível em: <https://www.revistas2.uepg.br/index.php/praxiseducativa > 
Pablo del Río, Elizabeth dos Santos Braga, Teresa Cristina Rego e Ana Luiza Bustamante Smolka

que você considere, vai nos levar a isso. Então, no fim, vamos descobrir que temos de realizar atividades globais, de operadores matemáticos ou outras formas de operadores em química, ou levar ao teatro para entrar na literatura. Vamos nos encontrar planejando atividades, mas não atividades no vazio, e sim atividades com todo um instrumental e com toda uma maquinaria para ajudar o professor.

O professor está muito sozinho. Impuseram-lhe burocracias e uma enorme quantidade de mandamentos carregados de pseudoteoria, conceitos burocráticos, científicos e psicológicos, proibições, o formato classe, muitas coisas. E realmente, em pedagogia, aprende-se o que se aprende, o que se pode. A educação é muito difícil porque se burocratizou enormemente, fragmentou-se. Fez-se dela um grande aparato. Não são os grandes aparatos e as instituições que desenvolvem a criança, mas, sim, as pessoas.

Entrevistadora: É muito pertinente a sua critica à própria perspectiva histórico-cultural e como ela tem sido excessivamente teórica. Também são relevantes suas reflexões sobre problemas e necessidades de mudança na educação das crianças e dos jovens. Gostaríamos de lhe pedir que explorasse um pouco mais essa questão e que a relacionasse ao conceito que seu grupo tem desenvolvido de "dieta cultural" para a construção do imaginário.

Pablo del Río: Os humanos vivem na ecologia do presente, mas, graças ao mecanismo de mediação, temos conseguido construir também uma segunda ecologia, que não substitui, mas é adicionada à anterior, constituída por um mundo de entidades e ações não presentes, um imaginário, em que a própria pessoa está incluída. O tema clássico da construção da realidade (a construção do mundo e a própria identidade), portanto, estende-se a dois mundos; vivemos em duas ecologias. Por uma parte, a humanidade reconstrói a primeira ecologia do presente, o mundo situado, inserindo nele instrumentos psicológicos e ritos sociais, transformando a ecologia animal em uma narrativização da vida que sempre converte a situação direta em outra coisa.

A construção da segunda ecologia - a construção do imaginário - enquanto normalmente nos resulta invisível, é um assunto mais elusivo para a investigação e para a educação. Podemos encontrar assuntos relacionados em Vigotski no último capítulo de "Pensamento e Linguagem", em suas alusões à teoria do drama na "Psicologia Concreta", e em "Psicologia da Arte".

O imaginário se constrói nas narrativas, nos contos, nas novelas ${ }^{27}$, nas parábolas, nos filmes, nas séries... Em cada época histórica e em cada geração, os meios e os gêneros em que se constrói o imaginário variam. E em cada idade e até para cada pessoa existem meios principais, constituintes. No meu tempo, eram a novela e o filme, mas as novas gerações constroem seu imaginário a partir dos scripts da publicidade, dos videogames e das séries de televisão. Alteram-se os meios e modificamse os conteúdos. A partir da metáfora da dieta, mudam a cozinha e os alimentos com que se constrói o imaginário.

$\mathrm{Na}$ construção do imaginário, existem duas partes essenciais estreitamente relacionadas: a construção do mundo e a construção da identidade. Construímos um mundo imaginado que vamos habitar como personagens de nós mesmos. Para a primeira ecologia, necessitamos de um mundo situado habitável e um papel nesse mundo situado. Para a segunda, necessitamos de um imaginário

\footnotetext{
${ }^{26}$ A tradução da obra Pensamento e Linguagem diretamente do russo para o português intitula-se $A$ construção do pensamento e da linguagem, publicada pela Martins Fontes, com tradução de Paulo Bezerra (VYGOTSKI, 2000b). O entrevistado faz alusão ao texto Psicologia concreta do homem, publicado em português na revista Educação \& Sociedade, n. 71 , em 2000. Quanto ao último texto mencionado, ver nota 24.

27 Mantivemos o termo espanhol "novela" que existe também em português, no sentido de uma narrativa breve, romance. O entrevistado usa o termo com o significado ora de romance, ora de história.
}

Práxis Educativa, Ponta Grossa, v. 17, e2219944, p. 1-24, 2022 Disponível em: <https://www.revistas2.uepg.br/index.php/praxiseducativa> 
de qualidade e uma identidade viável, um projeto de nós próprios, que impulsione nosso desenvolvimento. Nós observamos, hoje, na Espanha, problemas sérios na construção cultural de ambas as ecologias, a situada e a imaginária. Nem o mundo que estamos construindo nem o papel dos jovens no mundo e suas oportunidades de protagonismo positivo estão claros.

Necessito saber quem sou e preciso que minha vida tenha sentido e, então, atribuo a mim sentido e importância. A partir daí, posso atuar. Contudo, realmente, uma das coisas que nos preocupa muito na Espanha é o esfacelamento da identidade dos jovens: tudo para os jovens sem os jovens. Ou seja, não são ninguém na sociedade. São colocados na escola e logo depois nas tendências do consumo, mas, na realidade, não estão sendo protagonistas de nenhuma vida ou história.

\section{Entrevistadoras: Na sua óptica, o protagonismo se aprende. E isso tem relação com a "dieta cultural" que oferecemos aos jovens, não é mesmo?}

Pablo del Río: McClelland, psicólogo social e antropólogo, investigou o protagonismo em duas culturas indígenas nos Estados Unidos. Ele descobriu que, numa das culturas, a vida em geral ia bastante bem, resolviam qualquer dificuldade que se lhes apresentava. Já a outra cultura era mais limitada; as pessoas muitas vezes agiam sem capacidade de confronto com as coisas que lhes aconteciam. Então, ele analisou os relatos, contos, lendas que contavam às crianças. E descobriu que os relatos incorporavam ou não o herói que enfrenta problemas. A partir daí, propôs-se outra investigação complementar muito parecida. Pesquisou os relatos que as gerações que construíram os grandes impérios liam: analisou os relatos que os castelhanos liam na segunda metade do século XV; os ingleses, na segunda metade do século XVIII; e os estadunidenses, no final do século XIX e princípio do XX. Ele descobriu que se confirmava o que havia visto no outro estudo: eram relatos de protagonismo. O filósofo David Hume expressou-se muito bem quando disse que os castelhanos eram consumidores de novelas de cavalaria, e que isso os levou em várias gerações a enfrentar obstáculos. A aproximação às narrativas constituintes das grandes atitudes diante da vida e a ação não se aplica somente às tribos e aos impérios, mas, sim, a cada pessoa e a cada geração de cada cultura. Todos somos uma pequena tribo. E, no fundo, tampouco se trata de conquistar impérios. Trata-se, sim, de conquistar a vida, de a criança ter desde o princípio uma ideia de atividade, de estar nas coisas e de enfrentá-las, e de saber que ela é alguém. O filósofo Miguel de Unamuno o disse de maneira clara: enquanto tem consciência, o ser humano necessita, para viver plenamente sua vida, escrevê-la. E o necessitam também as culturas, os grupos, os países. Unamuno fala da necessidade de escrever três novelas: a novela da pessoa, a novela do país, a novela da humanidade.

Desde o Quixote inspirado pelas novelas de cavalarias, a motivação de enfrentamento ou de realização de McClelland, ou o termo atual de resiliência, os psicólogos estão buscando a capacidade de enfrentar a vida e de resolver problemas esquecendo a peça principal que é o protagonista. É a identidade, o sujeito, o que permite suportar o edifício pessoal e todas as funções. Cada criança deve ser pessoa a partir de um personagem, a partir de um projeto pessoal, de uma novela vital, em que esta tem um conteúdo protagonizado. É o que, a partir de tradições literárias como a russa ou a espanhola, entendeu-se como autoria vital.

O ser humano precisa de um imaginário do passado e do futuro, do que não está presente; necessita de uma narrativa, um mapa diretivo da vida. Eles lhe permitem reconstruir o organismo como pessoa - ter uma identidade e uma história - e reconstruir seu ecossistema como universo ter uma cosmologia, uma weltanschanung ${ }^{28}$. É por isso que Vigotski disse que o modelo da mente

${ }^{28}$ Pode ser traduzido do alemão por "cosmovisão", "visão de mundo”, “ideologia”.

Práxis Educativa, Ponta Grossa, v. 17, e2219944, p. 1-24, 2022 Disponível em: <https://www.revistas2.uepg.br/index.php/praxiseducativa> 
Pablo del Río, Elizabeth dos Santos Braga, Teresa Cristina Rego e Ana Luiza Bustamante Smolka

não é a razão, mas o drama. ${ }^{29}$ Sentimos e pensamos em drama. Vivemos em drama. Porque o desenvolvimento humano das funções superiores, tal como propunha Vigotski, não está garantido pela herança genética, mas é um esforço pessoal e coletivo, cultural, intransferível, de desenvolvimento, uma ascese. E uma ascese requer que a pessoa - ou a sociedade, a cultura - se ponha em marcha e se ocupe ativamente de seu próprio desenvolvimento como uma aventura pessoal. E isso é drama, novela.

Isso significa que a criança precisa construir para si mesma um personagem e um mundo simbólico: um imaginário. Os sistemas educativos têm deixado de dar importância a isso. Todavia, é central. E os imaginários que os meios de comunicação constroem são, muitas vezes, fragmentários, caóticos, contraditórios, inclusive irresponsáveis e destrutivos, com frequência. Parecem desfiles de moda em que a pessoa assume papéis que ela vai trocando como se mudasse de roupa. Os conteúdos da cultura simbólica são os materiais com que as crianças e os adultos constroem o mapa da vida, o imaginário e a novela própria e a coletiva. Se são de má qualidade, ou fragmentados e carentes de estrutura e eixo narrativo, nossa vida tenderá a ser também. Se eles são elevados, nos elevarão. Nós estamos analisando esses imaginários por meio de uma ferramenta metodológica - as análises de conteúdo - empregada na perspectiva de identificar a dieta do espírito - chamamos de "dieta cultural" - de maneira tão sistemática, como um nutricionista estuda a dieta alimentar de uma pessoa ou de um país. E os resultados são mais preocupantes do que tranquilizadores.

Entrevistadoras: Quer dizer que, de modo geral, a "dieta" que estamos oferecendo às novas gerações é deficitária on de má qualidade, do ponto de vista simbólico, imaginário? E esse quadro se agrava na medida em que a escola oferece poucas oportunidades em termos de protagonismo?

Pablo del Río: Sem dúvida. Nesse sentido, assim como se reconhece que há um crescente analfabetismo funcional (a leitura e a escrita que a criança aprende na escola frequentemente é pouco usada e se deteriora na vida real), comprovamos a extensão de um analfabetismo do imaginário. Nem os meios de comunicação, nem a escola estão ajudando muito a enfrentá-lo.

A criança precisa de bons modelos de vida dramática para protagonizar. E necessita também de ocasiões para exercer o protagonismo. De acordo com as culturas, as oportunidades de protagonismo podem ser escassas. No entanto, a criança necessita delas para que possa se desenvolver e aprender, tanto quanto de pão e água.

A escola, às vezes, esfacela: você não se dá conta de que, passando por um professor e por outro e por outro, essa criança não fez nada pessoalmente, não foi ninguém durante hoje, nem amanhã. Não foi ninguém. A escola foi somente: "façam todos este exercício". A criança tem de ter uma identidade reconhecida e ativa, não uma identidade de que somente a chamem pelo nome, mas também que haja atividades que Marcelo faz e que todo mundo sabe que Marcelo faz. A identidade tem de estar carregada de atividade, de papéis. Isso Bronfenbrenner ${ }^{30}$ dizia muito bem quando falava em papéis ativos e papéis passivos. A criança tem de estar vinculada a papéis, os quais ela possa exercer, e a pessoas com distintos papéis com as quais ela possa interatuar, porque senão tudo isso é faz de conta, é falso. Papéis que sejam exercidos e reconhecidos. Evidentemente, a escola tem de dar à criança oportunidades, não apenas de desafio, mas também de êxito. Bronfenbrenner também postula o apoio e o desafio. A criança necessita de estabilidade, necessita

\footnotetext{
${ }^{29} \mathrm{Na}$ primeira parte desta entrevista (publicada na Educação e Pesquisa, v. 39, n. 2, 2013), a questão do conceito de "drama" em Vigotski está mais detalhada.

${ }^{30}$ Urie Bronfenbrenner (1917-2005) foi um psicólogo russo que viveu e atuou nos Estados Unidos, conhecido por sua teoria de sistemas ecológicos para o desenvolvimento infantil.
}

Práxis Educativa, Ponta Grossa, v. 17, e2219944, p. 1-24, 2022 Disponível em: < https://www.revistas2.uepg.br/index.php/praxiseducativa $>$ 
ter um quartel a partir do que planeja suas conquistas, precisa estar segura de que é querida. E também necessita do desafio, porque senão a vida é muito aborrecida, e ela tampouco pode se sentir alguém, se não consegue fazer coisas. Então, a vida escolar é enormemente aborrecida e vazia em termos de protagonismo.

Carlos Carvalho da Costa, discípulo português de Amelia Álvarez, em seu doutoramento ${ }^{31}$, estava preocupado com o que ele chamava de protagonismo político, e disse: "Por que agora em Portugal há tão poucos líderes políticos ou muitos líderes políticos que são burocratas?”. E ela lhe disse: "De onde vem a liderança política? Como se forma?". Começamos a falar das atividades significativas na escola e que a liderança política se aprende na vida, que são oportunidades de exercer a iniciativa. A partir daí, ele, que era jornalista e educador, tentou fazer um jornal em sala de aula. Amelia Álvarez lhe disse para unir as duas coisas e ver em que medida fazer um jornal em sala pode gerar protagonismo e, ao mesmo tempo, fazer um sistema de atividades significativas em vez das disciplinas. Demos uma formação histórico-cultural durante um ano aos professores de uma escola que aceitaram entrar no jogo e, então, eles redefiniram todo o currículo tomando como base uma grande atividade significativa ao redor do jornal. Fizeram um jornal com todas as crianças, o qual não podia ser "de faz de conta". Era um jornal de verdade, que se imprimia na rotativa do jornal normal de adultos. Quando saiu o jornal, as crianças ficaram exultantes. Algumas crianças que não conseguiam aprender a ler e a escrever tinham um papel, todas tinham. Isso mudou a vida delas na escola. Assim, o protagonismo é identidade e é ação. Nesse sentido, muitas das tradições das escolas ativas que tiveram imagem tão boa, seria preciso recuperá-las.

Entrevistadoras: A questão da atenção também é algo muito preocupante e sabemos que é um tema sobre o qual você já se debruçou. Qual é sua opinião sobre a disseminação de diagnósticos do chamado "Transtorno do Déficit de Atenção com Hiperatividade", tão em voga atualmente?

Pablo del Río: Há uma junção mal-entendida em boa parte dos modelos atuais sobre o diagnóstico da atenção: os problemas de hiperatividade e os problemas de desatenção estão sendo postos juntos em um mesmo tipo de construto, que é o construto do Transtorno do Déficit de Atenção com Hiperatividade (TDAH). Na perspectiva vigotskiana ou na de Galperin ${ }^{32}$, a atividade e a atenção não são dois componentes de um transtorno, mas, sim, dois componentes essenciais do desenvolvimento humano. Para Galperin, a atenção é a atividade de orientação. A atenção superior humana é uma atenção mediada ou regulada, mediante operadores que permitem orientar e controlar a atividade. As atividades produtivas tradicionais (como a cozinha, a colheita) contam normalmente com uma estruturação cultural que garante que a criança tenha atividade e que esta conte com psicotecnias e operadores instrumentais e sociais de regulação mediada da atenção, uma atenção sustentada e necessária para levar a cabo a atividade. Temos, pois, atenção + atividade, ambas com realização funcional, com um reforço claro para que a criança mantenha unidas e bem articuladas a atenção e a atividade. Entretanto, esse tipo de atividade falta cada vez mais na vida das crianças atuais.

Então, se você tira a atividade da vida da criança, fora da escola, ficam objetos de consumo, e ainda por cima muito fragmentados, que são problemáticos para a atenção e para a própria

\footnotetext{
31 Trata-se da tese intitulada O jornal escolar como ferramenta de desenho educativo no currículo. Uma proposta de intervenção baseada no conceito de actividade significativa, defendida na Universidade de Salamanca, em 2006.

32 O psicólogo russo Piotr Yakovlevich Galperin (1902-1988) foi contemporâneo de Vigotski e continuador de suas ideias. De acordo com sua perspectiva, por meio de um ensino planejado, é possível alcançar a formação de processos mentais a partir da atividade externa.
}

Práxis Educativa, Ponta Grossa, v. 17, e2219944, p. 1-24, 2022 Disponível em: <https://www.revistas2.uepg.br/index.php/praxiseducativa > 
Pablo del Río, Elizabeth dos Santos Braga, Teresa Cristina Rego e Ana Luiza Bustamante Smolka

atividade. Se você tira a atividade do cotidiano da criança e, também, na escola, obviamente surgirão problemas de desatenção e de hiperatividade.

\section{Entrevistadoras: Desse modo, o problema é histórico e é cultural e não simplesmente uma patologia apresentada por} determinado indivíduo e, portanto, o fenômeno não pode ser analisado fora de um contexto mais amplo.

Pablo del Río: Claro, e isso é o que não se está levando em conta. Estamos numa sociedade desatenta, na qual não há atividade estruturante. A atividade estruturante estrutura e, se estrutura, desenvolve atividade voluntária. E, se não há atividade, o que surge? A hiperatividade. E o que é a hiperatividade? Uma atividade não orientada. Então, o corpo não se aguenta e não sabe o que fazer. $\mathrm{E}$, ao mesmo tempo, a criança não tem atenção porque não tem a atividade estruturada. E a atenção voluntária não é outra coisa que a antecipação do que vai acontecer e ferramentas para antecipar e para regular o que estou fazendo. Num vazio de atividade produtiva estruturante, a atividade vai por um lado e a atenção por outro; a atividade é anárquica, a atenção é involuntária e direta. Então, a partir daí, os dois efeitos são imediatos. Hiperativos? Hiperativos somos todos: se ativos ou proativos como agora se diz, é uma questão de se ter conseguido canalizar esse impulso natural à atividade em direção a atividades produtivas, bem reguladas, e dotadas de realização funcional. Simplesmente, atividades orientadas pela atenção mediada.

A esse respeito, nós encontramos que essa psicopatologia apresenta matizes de gênero. Os meninos tendem a ser mais hiperativos do que as meninas. Os meninos têm um componente psicomotor de uma estrutura de descarga tônica muito maior. É verdade que a sociedade tem sido muito discriminatória com a mulher, mas o fato é que, neste momento, o menino está fracassando: $80 \%$ dos problemas de delinquência são de meninos, $80 \%$ de população infantil e juvenil reclusa são de meninos. A porcentagem mais alta de fracasso escolar, de encaminhamentos para o psicólogo e o psiquiatra e de transtornos mentais é de meninos.

Infelizmente, temos problemas de sobra que constituem perigos tanto para o menino como para a menina. É correto dizer que meninos e meninas têm uma necessidade de atividade, mas há uma diferença. Houve dois fenômenos que nós vimos na investigação que fizemos sobre a vida cotidiana da criança espanhola que vale a pena mencionar: as meninas mantêm mais atividades cotidianas porque trabalham em atividades domésticas: cozinham, limpam. Entretanto, as meninas espanholas já não, porque já cozinham tão pouco como os meninos, não limpam. Contudo, a igualdade ideal seria que todos fizessem tudo. A igualdade ideal não seria tirar a atividade produtiva das meninas; seria que os meninos também a tivessem. Então, esse é um fator que estava beneficiando as meninas.

O sedentarismo é algo horrível; necessitamos de atividade. Se você tira a atividade, o que tem? Tem sedentarismo, falta de atenção, hiperatividade, desengajamento escolar. E se você tira atividades significativas na casa? Isso aconteceu também com o homem. O homem do campo que tinha sua própria exploração agrícola sabia fazer de tudo, estava durante todo o dia fazendo coisas. Quando as populações migraram para a cidade, o homem passou a ter um trabalho numa fábrica, mas em casa não fazia nada. A primeira geração ainda fez, porque se educou no campo e sabia que tinha de fazer algo em casa. Então, punha-se a pintar a casa, fazer uma mesa, etc. À medida que o tempo passa, os homens nas cidades se tornam uns inúteis. Não sabem fazer nada. A mulher ainda administra um pouco a casa. E aqui há um problema sério: rompemos o tecido cultural de atividade. É preciso recuperar a atividade estruturada e produtiva. Como? Não sei, dependerá de cada lugar. 
Entrevistadoras: $N$ a realidade brasileira, as crianças mais pobres estão sempre em atividade até porque muitas ajudam os pais em casa ou em trabalhos informais. Muitas chegam à escola cansadas. Nesse caso, talvez não seja um problema de sedentarismo, mas o contrário: de excesso de atividades. No entanto, é uma atividade talvezpouco significativa, sem um sentido escolar, relacionado ao conhecimento. Muito parecido com aquilo que Philippe Ariès na História social da criança e da família nos conta sobre a invenção da infância: eles são pequenos adultos trabalhadores. Todavia, essa ideia de uma sociedade contemporânea que leva a uma espécie de hiperatividade é muito interessante porque, no âmbito escolar, o que se costuma faz̧er é medicalizar e patologizar o problema.

Pablo del Río: Nesse caso, a criança necessita de atividades que abram outros horizontes, mas os horizontes do espírito, do saber, também requerem atividade. A fadiga física não impede necessariamente que a criança interessada em uma atividade bem programada se envolva. O que é comumente chamado preguiça ou desatenção na escola é, muitas vezes, desinteresse. Na Espanha, é preocupante o alto grau de incidência do desengajamento psíquico na escola. Esse desengajamento psíquico entre a criança e a escola está sendo rotulado e diagnosticado com diversas denominações de "patologias" psíquicas. Entretanto, o que temos é uma patologia cultural e pedagógica, institucional.

Nosso organismo se constrói a partir da atividade; não pode suportar sem dano um vazio de atividade. Se isso ocorre, busca a saída por qualquer meio, bom ou mal. Passei boa parte de minha infância num internato na cidade. Contudo, eu passava os verões num povoado de meus avós e ali eu montava a cavalo e tinha muitas oportunidades de atividades significativas, de realização funcional, de desafio. Se você não tem, o que você faz? Você busca. E como a busca? Por meio do alcoolismo, das drogas, por exemplo. Você necessita da realização funcional, de atividades significativas. Não podem tirar isso de você e, se o tiram, você o busca. Daí o fracasso. E, então, clinica-se ou se converte em delinquência. Nesse caso, estar fracassando não é o extraordinário; é o normal. As crianças não têm o que necessitam e, por isso, o buscam noutro lugar.

Se faltam condições mais positivas e construtivas de desenvolvimento (o que Espinoza chamava afetos positivos), recorremos aos afetos negativos, a estímulos emocionais que nos tiram e nos dão saída sem um efeito construtivo. O fator mais importante, então, é que as crianças necessitam da droga porque deixaram de ter o que fazia com que recorrer à droga não fosse necessário. Assim, se os garotos e as garotas têm uma identidade, têm um protagonismo, uma atividade significativa e a vida explode em oportunidades de autorrealização e de promessas para o futuro, pode acontecer que, em algum momento, se droguem, mas não ficarão tão presos a isso, porque é uma interação entre uma água corrente que vai por aqui e uma água parada que freia a corrente. Todavia, se você está numa corrente, um rio forte poderoso de atividade, o outro não vai ter esse impacto. Por trás de tudo isso, há uma cultura tanto científica como popular que gerou uma perspectiva de imobilismo, na sociedade de um excesso de informação, mas certamente muito pouca sabedoria e atividade. É um mundo que se estabeleceu sobre a cultura dos últimos trinta ou quarenta anos, que se equivocou, do meu ponto de vista.

Fala-se de aquecimento global como uma mudança material, mas eu me preocupo com a mudança psicológica. Não porque os jovens sejam melhores ou piores que nós, mas porque têm problemas muito mais graves do que tivemos: podem até comer mais, ter mais coisas materiais (parte deles, pelo menos), mas têm muito mais problemas de outro tipo. É um momento muito complicado para as novas gerações. E nós, educadores, estamos enredados nesses movimentos imobilistas e felizes no consumo e na informação, e há fatos que são muito candentes, muito preocupantes e práticas que nos imobilizam quase que totalmente para fazer algo. O problema da educação hoje é sério e provavelmente é necessário fazer um questionamento muito profundo e vigoroso do que faz falta abordar para voltar a tratar do problema do desenvolvimento humano.

Práxis Educativa, Ponta Grossa, v. 17, e2219944, p. 1-24, 2022 Disponível em: <https://www.revistas2.uepg.br/index.php/praxiseducativa $>$ 
O que é relevante na educação não é o problema do currículo e do conhecimento, mas, sim, o do desenvolvimento humano.

Ultimamente minhas reflexões sobre educação me fazem ver que esforços educacionais têm se centrado no conhecimento e têm encapsulado a criança no ambiente escolar. E isso tem levado a uma paralisia evolutiva e moral das crianças e educadores. Na perspectiva eco-históricocultural, a educação não pode ser separada do desenvolvimento humano, social e cultural nem tampouco da vida ao redor. Somos uma espécie diretiva, que necessita construir-se, que precisa sempre de um projeto vivo e um plano de autorrealização; uma espécie cujo desenvolvimento e educação são sempre um esforço e uma aventura. E, no momento histórico atual, o desafio é um dos mais altos já confrontados pela humanidade e pela instituição educacional. Eu sinceramente acredito que é o momento de fazermos uma profunda reavaliação dos modelos educacionais, de um novo despertar educacional.

Foto 1 - Pablo del Río - Sede da Fundación Infancia y Aprendizaje - Madri - 2020

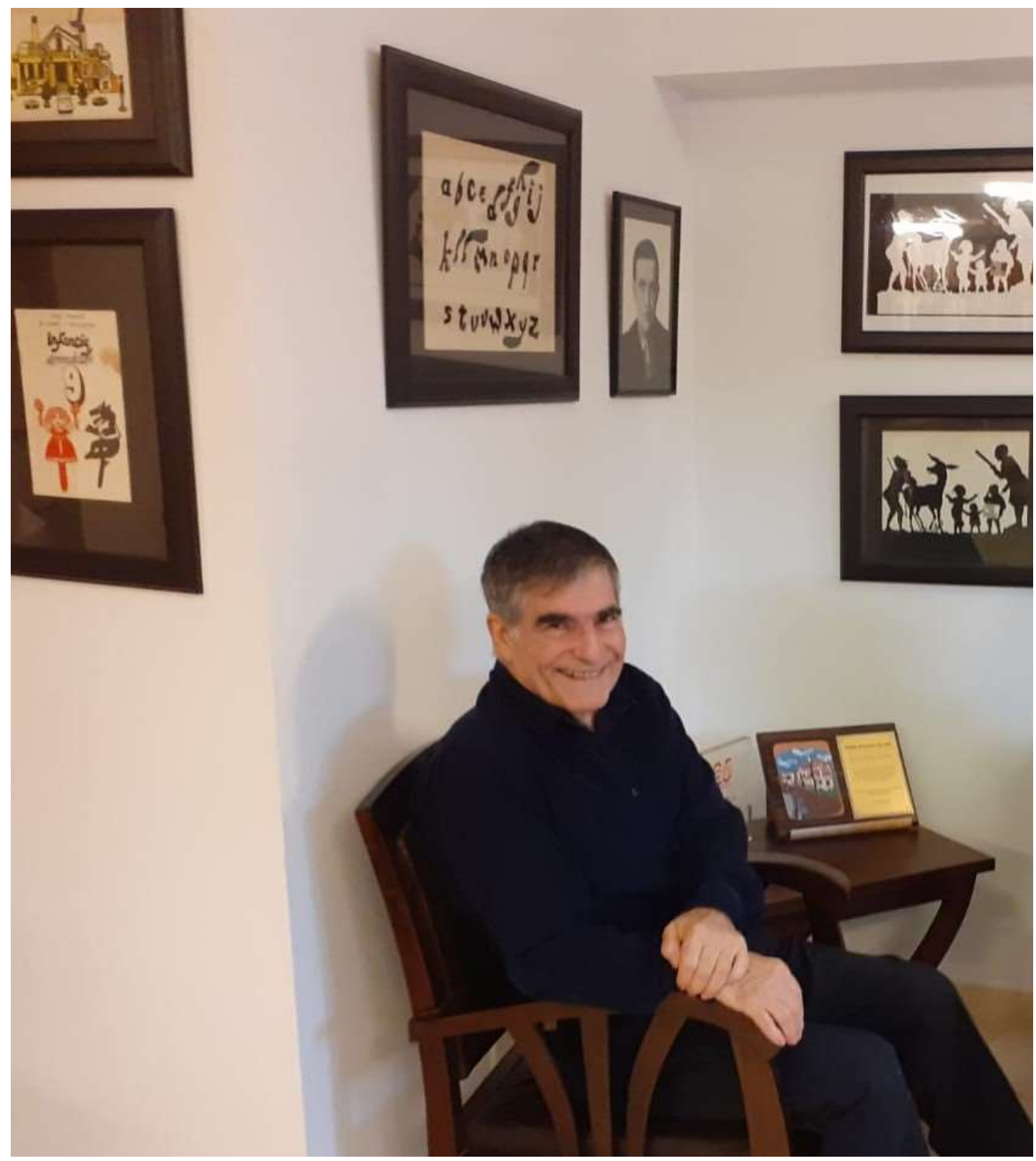

Fonte: Arquivo pessoal de Beatriz Braga Coelho.

Práxis Educativa, Ponta Grossa, v. 17, e2219944, p. 1-24, 2022 Disponível em: <https://www.revistas2.uepg.br/index.php/praxiseducativa> 
Foto 2 - Pablo del Río e Amelia Álvarez - Sede da Fundación Infancia y Aprendizaje - Madri - 2020

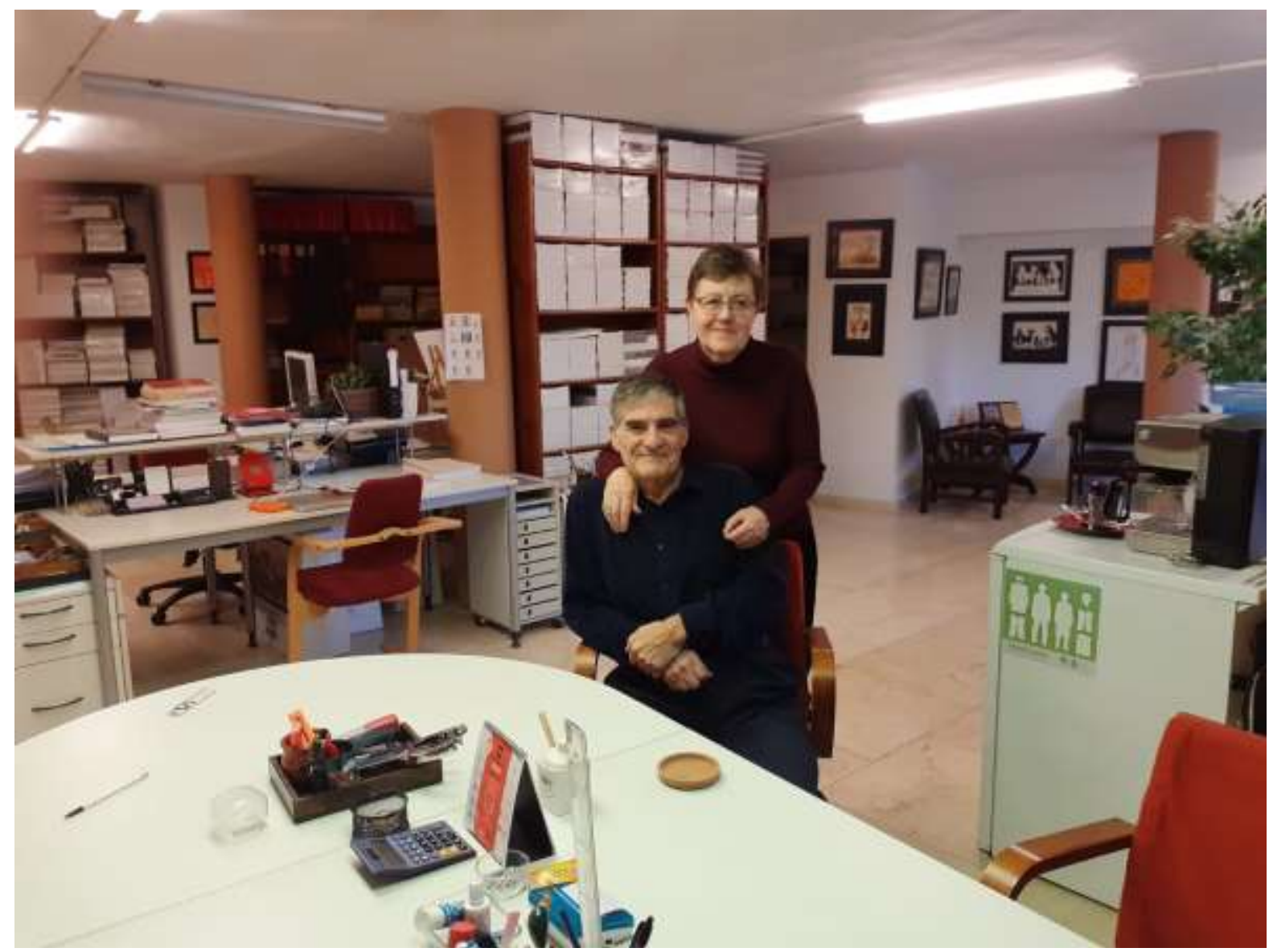

Fonte: Arquivo pessoal de Elizabeth dos Santos Braga.

\section{Referências $^{33}$}

CARVALHO, J. S. F. Um sentido para a experiência escolar em tempos de pandemia. Educação \& Realidade, Porto Alegre, v. 45, n. 4, p. 1-13, 2020. DOI: https://doi.org/10.1590/2175$\underline{6236109144}$

COSTA, C. C. O jornal escolar como ferramenta de desenho educativo no currículo. Uma proposta de intervenção baseada no conceito de actividade significativa. 2006. Tese (Doutorado em Sociologia e Comunicação) - Universidade de Salamanca, Salamanca, 2006.

DANTAS, H. A afetividade e a construção do sujeito na psicogenética de Wallon. In: LA TAILLE, Y.; OLIVEIRA, M. K. de; DANTAS, H. (org.). Piaget, Vygotsky, Wallon: teorias psicogenéticas em discussão. São Paulo: Summus, 1992. p. 85-98.

DEL RÍO, P.; ÁLVAREZ, A. El cuerpo del espíritu. Presentación de esta edición. In: ZAZZO, R. (ed.). El yo social. La psicología de Henry Wallon. Tradução P. Del Río e A. Álvarez. Madrid: Fundación Infancia y Aprendizaje, 2004. p. 11-16.

DEL RÍO, P.; ÁLVAREZ, A. ¿Saber o comportarse? El desarrollo y la construcción de la directividad. In: ÁLVAREZ, A. (ed.). Hacia un currículum cultural: la vigencia de Vygotski en

\footnotetext{
${ }^{33}$ Trata-se das obras referidas na apresentação e nas notas do texto da entrevista.
} 
la educación. Madrid: Fundación Infancia y Aprendizaje, 2006. p. 101-131.

DEL RÍO, P.; ÁlVAREZ, A. Prayer and the Kingdom of Heaven. Psychological tools for directivity. In: VALSINER, J.; ROSA, A. (ed.). The Cambridge Handbook of Sociocultural Psychology. Cambridge, Massachusetts: Cambridge University Press, 2007a. p. 373-403.

DEL RÍO, P.; ÁLVAREZ, A. De la psicología del drama al drama de la psicología. La relación entre la vida y la obra de Lev S. Vygotski. Estudios de Psicología, [s. l.], v. 28, n. 3, p. 303-332, $2007 \mathrm{~b}$.

DEL RÍO, P.; ÁlVAREZ, A. El déficit de actividad como problema de desarrollo. Algunos potenciales educativos del eco-funcionalismo y la psicología histórico-cultural. Cultura y Educación, [s. l.], v. 23, n. 4, p. 601-619, 2011.

DEL RÍO, P.; ÁLVAREZ, A. El desarrollo cultural y las funciones superiores: del pasado al futuro. In: SMOLKA, A. L. B.; NOGUEIRA, A. L. H. (org.). Estudos na perspectiva de Vigotski: gênese e emergência das funções psicológicas. Campinas: Mercado das Letras, 2013. p. 15-69.

DEL RÍO, P.; ÁlVAREZ, A.; DEL RÍO, M. Pigmalión: Informe sobre el impacto de la televisión en la infancia. Madrid: Fundación Infancia y Aprendizaje, 2004.

DEL RÍO, P.; REGO, T. C.; BRAGA, E. S. Dos desafios para a psicologia histórico-cultural à reflexão sobre a pesquisa nas ciências humanas: entrevista com Pablo del Río. Educação e Pesquisa, São Paulo, v. 39, n. 2, p. 509-540, 2013.

LIBÂNEO, J. C.; FREITAS, R. A. M. M. Vasily Vasilyevich Davydov: a escola e a formação do pensamento teórico-científico. In: LONGAREZI, A. M.; VALDÉS PUENTES, R. (org.). Ensino desenvolvimental: vida, pensamento e obra dos principais representantes russos. Uberlândia: EDUFU, 2013. p. 315-350.

LURIA, A. R. A Construção da mente. Tradução M. B. Cipolla. São Paulo: Ícone, 1992.

NEPOMUCENO, Eric. Uma grande história nas mãos de um grande escritor: Eric Nepomuceno escreve sobre Hereges, de Leonardo Padura. Blog da Boitempo, 6 out. 2015. Disponível em: https://blogdaboitempo.com.br/2015/10/06/uma-grande-historia-nas-maos-de-um-grandeescritor-eric-nepomuceno-escreve-sobre-hereges-de-leonardo-padura/. Acesso em: 11 jan. 2022.

OLIVEIRA, M. K. O problema da afetividade em Vygotsky. In: LA TAILLE, Y.; OLIVEIRA, M. K. de; DANTAS, H. (org.). Piaget, Vygotsky, Wallon: teorias psicogenéticas em discussão. São Paulo: Summus, 1992. p. 75-84.

PALACIOS, J.; VILA, I. Présence, impact et actualité de l'oeuvre de Wallon. Enfance, [s. l.], v. 47, n.1, p. 33-42, 1993. DOI: https://doi.org/10.3406/enfan.1993.2040

POLITZER, G. Crítica dos fundamentos da psicologia: a psicologia e a psicanálise. Tradução M. Marciolino e Y. M. C. T. Silva. 2. ed. Piracicaba: Editora da UNIMEP, 2004.

SÁNCHEZ-BARBUDO, A. Introduccion. In: UNAMUNO, M. Del sentimiento trágico de la vida. La agonía del cristianismo. Madrid: Akal, 2017. p. 7-53.

SMOLKA, A. L. B. et al. O problema da avaliação das habilidades socioemocionais como política pública: explicitando controvérsias e argumentos. Educação \& Sociedade, Campinas, v. 36, n. 130, p. 219-242, jan./mar. 2015. DOI: https://doi.org/10.1590/es0101-73302015150030 
UNAMUNO, M. Del sentimiento trágico de la vida. La agonía del cristianismo. Madrid: Akal, 2017.

VIGOTSKI, L. S. Teoría de las emociones: estudio histórico-psicológico. Madrid: Ediciones Akal, 2004.

VIGOTSKI, L. S. Teoria e Método em Psicologia. Tradução C. Berliner. São Paulo: Martins Fontes, 1996.

VIGOTSKI, L. S. O desenvolvimento psicológico na infância. Tradução C. Berliner. São Paulo: Martins Fontes, 1999a.

VIGOTSKI, L. S. A tragédia de Hamlet, príncipe da Dinamarca. Tradução de P. Bezerra. São Paulo: Martins Fontes, 1999b.

VIGOTSKI, L. S. Psicologia da Arte. Tradução P. Bezerra. São Paulo: Martins Fontes, 1999c.

VIGOTSKI, L. S. Manuscrito de 1929. Tradução A. Marenitch; L. C. de Freitas. Educação \& Sociedade, Campinas, ano XXI, n. 71, v. 21, p. 21-44, 2000a. DOI: https://doi.org/10.1590/S0101-73302000000200002

VIGOTSKI, L. S. A construção do pensamento e da linguagem. Tradução P. Bezerra. São Paulo: Martins Fontes, 2000b.

VIGOTSKI, L. S. Psicologia Pedagógica. Tradução P. Bezerra. São Paulo: Martins Fontes, 2010.

VIGOTSKI, L. S. Quarta aula: o problema do meio na pedologia. In: PRESTES, Z.; TUNES, E. (org.). Sete aulas de L. S. Vigotski sobre os fundamentos da pedologia. Tradução C. C. G. Santana. Rio de Janeiro: E-Papers, 2018. p.73-92.

WALLON, H. As origens do caráter na criança. Tradução H. Dantas. São Paulo: Nova Alexandria, 1995.

WALLON, H. A evolução psicológica da criança. Tradução C. Berliner. São Paulo: Martins Fontes, 2007.

Recebido em 04/01/2022

Aceito em 10/01/2022

Publicado online em 18/01/2022

Práxis Educativa, Ponta Grossa, v. 17, e2219944, p. 1-24, 2022 Disponível em: <https://www.revistas2.uepg.br/index.php/praxiseducativa > 